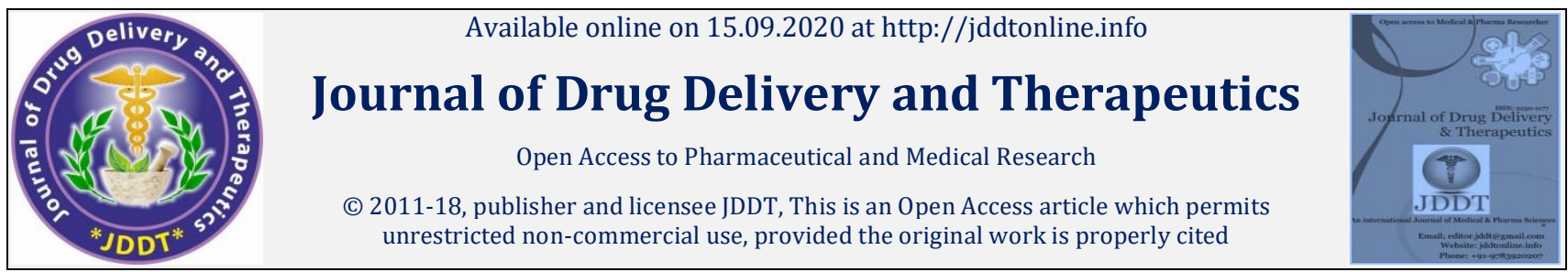

Open $\odot$ Access

Research Article

\title{
In-vitro and in-vivo anti-inflammatory activity of Plumeria indica Linn flowers
}

\author{
Narendraa Yadav, Sourabh Jain* Karunakar Shukla \\ College of Pharmacy, Dr. A. P. J. Abdul Kalam University, Village, Post, Indore Bypass Rd, Arandia, Jhalariya, Madhya Pradesh 452016
}

\begin{abstract}
Inflammation is a reaction of a living vascularised tissue to an injury. Conventional or synthetic drugs used in the treatment of inflammatory diseases are inadequate, it sometimes have serious side effects. So, number of herbal medicines is recommended for the treatment of inflammation that has no side effects. Hence our study focused to investigate the physicochemical, qualitative phytochemical analysis of bioactive compounds and In-vitro and In-vivo anti-inflammatory activity of Plumeria indica Linn $(P$. Indica) flowers extract which has boundless medicinal properties. The physicochemical evaluations carried out in terms of loss on drying, ash value, extractive values and acid insoluble ash value ect. Qualitative analysis of various phytochemical constituents was determined by the well-known test protocol available in the literature. The aqueous and ethanolic extract of $P$. Indica flowers was screened for in-vivo anti-inflammatory activity by carrageenan induced paw edema in rat model and in-vitro anti-inflammatory activity by human red blood cell membrane stabilization method. Phytochemical analysis revealed the presence of phenols, flavonoids, tannins, saponins, alkaloids ect. Ethanolic extract showed best in vitro anti-inflammatory activity was screened for in vivo anti-inflammatory activity at the dose level of 250 and $500 \mathrm{mg} / \mathrm{kg}$. Indomethacin at the dose level of $10 \mathrm{mg} / \mathrm{kg}$ was used as reference standard drug. Both the extracts showed a dose dependent anti-inflammatory potential which provide scientific basis for the traditional claims of $P$. Indica flowers as an anti-inflammatory drug.
\end{abstract}

Keywords: Plumeria indica Linn, Anti-inflammatory activity, Carrageenan, Human red blood cells membrane

Article Info: Received 09 July 2020; Review Completed 22 Aug 2020; Accepted 31 August 2020; Available online 15 September 2020

Cite this article as:

Yadav N, Jain S, Shukla K, In-vitro and in-vivo anti-inflammatory activity of Plumeria indica Linn flowers, Journal of Drug Delivery and Therapeutics. 2020; 10(5):168-174 http://dx.doi.org/10.22270/jddt.v10i5.4301

\section{*Address for Correspondence:}

D. Dr. Sourabh Jain, College of Pharmacy, Dr. A. P. J. Abdul Kalam University, Village, Post, Indore Bypass Rd, Arandia,

Jhalariya, MP 452016

\section{INTRODUCTION}

Inflammation is considered as a primary physiologic defense mechanism that helps body to protect itself against infections, burns, toxic chemicals, allergens or other noxious stimuli. An uncontrolled and persistent inflammation may act as etiological factor for many chronic illnesses 1 . Nonsteroidal anti-inflammatory drugs (NSAIDS) are widely used in the treatment of pain and inflammation. Currently available NSAIDS are associated with unwanted side effects and have their own limitations. About $34-46 \%$ of the users of NSAIDS usually sustain some gastrointestinal damage due to inhibition of the protective cyclooxygenase enzyme in gastric mucosa ${ }^{2}$. Hence there is a need for anti-inflammatory drugs with fewer side effects. Plants have been an important source of medicine for 1000's of years. Herbal medicine is still the mainstay of therapy for about $75-80 \%$ of the whole population in developing countries for primary health care 3 . This is because of better cultural acceptability, affordability, better compatibility with the human body and fewer or no side effects, in addition, the last few years have seen a major increase in the use of herbal remedies in developed countries 4. The long historical use of medicinal plants in many traditional medical practices, including experience passed from generation to generation, has demonstrated the safety and efficient value of traditional medicine 5. World Health Organization encourages the inclusion of herbal medicines of proven safety and efficacy in the healthcare programs of developing countries because of the great potential they hold in combating various diseases ${ }^{6}$. Many Indian ethno botanic traditions propose a rich repertory of medicinal plants used by the population for the treatment, management and/or control of different types of pain ${ }^{7}$. However, there were not enough scientific investigations on the anti-inflammatory and analgesic activities conferred to these plants. One such plant from Indian flora Plumeria indica Linn (Apocynacea). Plumeria is a fast-growing, medium size tree, that is botanically belongs to family Apocynaceae. The plant can reach a height up to 5-8 feet with many branches on the upper part. Small trees or herbs with obanceolate flowers. Flowers are alternate, bounded at twig tips, strongly recovered margin flowers are white, fragrant, in corymbose 
clusters. The white flowers bearing five petals and have fragrance. Iridoid glycosides were the first medicinally active compounds isolated from the species of Plumeria. Subsequently the latex and oil of some of these species were found to have other medicinally active constituents like sterols, carbohydrates, tannins, triterpenoids and alkaloids. Similar constituents were subsequently isolated from various extracts of roots and areal parts of these plants in varied comp ositions. Different species of Plumeria are used for the cure of rheumatism, diarrhoea, blennorhea, venereal disease, leprosy, psychosis and diuresis etc. Plumeria species have also been investigated for isolation of irridoids and triterpenoids, which exhibited algicidal, antibacterial and cytotoxic activities ${ }^{8}$. The aim of this work was to determine the quality (types), quantity (amount) of bioactive compounds and In-vitro and In-vivo anti-inflammatory activity of $P$. Indica flowers.

\section{MATERIALS AND METHODS}

\section{Plant material}

The flowers of plant $P$. indica were collected in the month of Jan-Feb 2019 from the Malwa region of Madhya Pradesh. The identification and authentication of plant was done by Dr. S.N. Dwivedi from the Department of Botany, Janata PG College, A.P.S. University, Rewa, MP. A voucher specimen number PI/432 was kept in Janata PG College, A.P.S. University, Rewa, MP for future reference.

\section{Chemical reagents}

All the chemicals used in this study were obtained from $\mathrm{Hi}$ Media Laboratories Pvt. Ltd. (Mumbai, India), Sigma-Aldrich Chemical Co. (Milwaukee, WI, USA), SD Fine-Chem Ltd. (Mumbai, India) and SRL Pvt. Ltd. (Mumbai, India).All the chemicals used in this study were of analytical grade.

\section{Physicochemical parameters}

The various physicochemical parameters that were determined as per The Unani Pharmacopeia of India 9 include the following

\section{Determination of loss on drying}

Two grams of crude powder was taken in an evaporating dish and then dried in an oven at $105^{\circ} \mathrm{C}$ till constant weight was obtained. The weight after drying was noted and loss on drying was calculated. The percentage was calculated on the basis of sample taken initially.

\section{Total ash}

$3 \mathrm{~g}$ of powdered drug was accurately weighed and taken in a tarred silica crucible which was previously ignited and weighed. The powdered drug was spread as a fine even layer on the bottom of the crucible. The crucible was incinerated gradually by increasing the temperature to make it dull red hot until free from carbon. The crucible was cooled and weighed. The ash was weighed and the total ash content was calculated with reference to the air dried drug.

\section{Acid insoluble ash}

The ash obtained as described in total ash was boiled with $25 \mathrm{ml}$ of dilute hydrochloric acid for 5 minutes. The insoluble ash was collected on an ashless filter paper and washed with hot water. This insoluble ash was transferred into a silica crucible and it was ignited, cooled and weighed. The process was repeated to get constant weight. The percentage of acid insoluble ash was calculated with reference to the quantity of air dried crude drug.

\section{Water soluble ash}

Total ash obtained was boiled for 5 minutes with $25 \mathrm{ml}$ of water. The insoluble matter was collected in ashless filter paper and washed with hot water. The insoluble ash was transferred into silica crucible and was ignited, cooled and weighed. The process was repeated to get constant weight. The weight of insoluble matter was subtracted from the weight of the total ash. The difference of the weight was considered as the water soluble ash. The percentage of water soluble ash was calculated with reference to the air dried drug.

\section{Solvent ether soluble extractive values}

Accurately weighed $5 \mathrm{gm}$ of powdered air dried leaves was taken with $100 \mathrm{ml}$ of solvent ether in a stopper flask and kept for 24 hours. The flask was shaken frequently (Maceration) then the solvent ether extract was filtered rapidly through filter paper to prevent excessive loss of solvent ether. $25 \mathrm{ml}$ of solvent ether extract was evaporated to dryness on a water bath and complete the drying in an oven at $100^{\circ} \mathrm{C}$.Then the residue was cooled weighed and kept in desiccators. Then the percentage $\mathrm{w} / \mathrm{w}$ of solvent ether soluble extractive with reference to the air-dried drug was calculated.

\section{Alcohol soluble extractive values}

Accurately weighed 5 gm of powdered air dried leaves was taken with $100 \mathrm{ml}$ of alcohol $(90 \% \mathrm{v} / \mathrm{v}$ ) in a stopper flask and kept for 24 hours. The flask was shaken frequently (Maceration).Then the alcohol extract was filtered rapidly through filter paper to prevent excessive loss of alcohol. $25 \mathrm{ml}$ of alcoholic extract was evaporated to dryness on a water bath and complete the drying in an oven $100^{\circ} \mathrm{C}$. Then the residue was cooled, weighed and kept in desiccators. Then the percentage $\mathrm{w} / \mathrm{w}$ of alcohol soluble extractive with reference to the air-dried drug was calculated.

\section{Water soluble extractive values}

Accurately weighed $5 \mathrm{gm}$ of powdered air-dried leaves was taken with $100 \mathrm{ml}$ of water in a stopper flask and kept for 24 hours. The flask was shaken frequently (Maceration).Then the aqueous extract was filtered rapidly through filter paper. $25 \mathrm{ml}$ of aqueous extract was evaporated to dryness on a water bath and complete the drying in an oven at $100^{\circ} \mathrm{C}$ Then the residue was cooled, weighed and kept in desiccators. Then percentage $\mathrm{w} / \mathrm{w}$ of soluble extractive with reference to the air dried drug was calculated.

\section{pH Value at $10 \%$ and $1 \%$ dilution}

pH of $10 \%$ Solution. An accurately weighed 10 gm of drug was dissolved in accurately measured $100 \mathrm{ml}$ of water and filtered and the $\mathrm{pH}$ of filtrate was checked with a standardized glass electrode.

$\mathrm{pH}$ of $1 \%$ Solution. An accurately weighed $1 \mathrm{gm}$ of drug was dissolved in accurately measured $100 \mathrm{ml}$ of water and filtered and the $\mathrm{pH}$ of filtrate was checked with a standardized glass electrode.

\section{Moisture content}

About 10 gm of drug will be taken in a evaporating dish and dried in the hot air oven at $105^{\circ} \mathrm{C}$ for 5 hour and weighed, continue the drying and weighed after 1 hour interval until difference between two successive weighing correspond to not more than $0.25 \%$ constant weight. Constant weight is reached when two consecutive weightings after drying for 30 min, in a desicator, show not more than $0.01 \mathrm{gm}$ difference. Then the percentage of loss on drying will be calculated with reference to the air dried drug. 


\section{Extraction}

Collected plant material washed under running tap water and kept in shade for drying. Dried plant materials were then powdered using blender and further observed for colour, odour and texture then placed in packed labeled air tight container for further use. Plant material was extracted by continuous hot percolation method using Soxhlet apparatus. Powdered material of flowers of $P$. indica was placed in thimble of soxhlet apparatus. Soxhlation was performed at $60^{\circ} \mathrm{C}$ using petroleum ether as non-polar solvent. Exhausted plant material (marc) was dried and afterward re-extracted with chloroform, ethanol and water as solvent. For each solvent, soxhlation was continued till no visual colour change was observed in siphon tube and completion of extraction was confirmed by absence of any residual solvent, when evaporated. Obtained extracts was evaporated using rotary vacuum evaporator (Buchi type) at $40^{\circ} \mathrm{C}$. Dried extract was weighed and percentage yield for each extract was determined 10 .

\section{Qualitative phytochemical analysis of plant extract}

The $P$. indica extracts obtained was subjected to the preliminary phytochemical analysis 11,12 . The extract was screened to identify the presence or absence of various active principles like phenolic compounds, carbohydrates, flavonoids, glycosides, saponins, alkaloids, fats or fixed oils, protein and amino acid and tannins.

\section{Animals}

Adult Albino rats of both sex (200-250 gm) were procured from Veterinary College, Mhow, Indore, (M.P.) had been group housed $(n=6)$ under a typical $12 \mathrm{~h}$ mild/dark cycle and controlled conditions of temperature and humidity $\left(25 \pm 2{ }^{\circ} \mathrm{C}\right.$, $55-65 \%)$. Rats got typical rodent chow and water advert libitum. Rats had been acclimatized to laboratory conditions for 7 days earlier than engaging in the experiments. All the experiments were carried in a noise-free room between 08.00 to $15.00 \mathrm{~h}$. Separate crew $(n=6)$ of rats was once used for every set of experiments. The animal reviews were approved through the Institutional Animal Ethics Committee (IAEC), constituted for the cause of manipulate and supervision of experimental animals through Ministry of atmosphere and Forests, government of India, New Delhi, India.

\section{Acute oral toxicity}

Acute toxicity study of the prepared flowers extracts of $P$. indica was carried out according to the Organization for Economic Co-Operation and Development (OECD) Guidelines-423 13 the animals were fasted for $4 \mathrm{~h}$, but allowed free access to water throughout. As per the OECD recommendations, the starting dose level should be that which is most likely to produce mortality in some of the dosed animals; and when there is no information available on a substance to be tested in this regard; for animal welfare reasons, The dose level to be used as the starting dose is selected from one of three fixed levels 5, 50, 300 and 2000 $\mathrm{mg} / \mathrm{kg}$ body weight. Acute toxicity was determined as per reported method 14 .

\section{In-vitro Anti-inflammatory activity by HRBC Methods}

The HRBC membrane stabilizing activity assay was carried out as reported by Sadique et al., 1989; Oyedapo et al., 2004 15,16 using $10 \%(\mathrm{v} / \mathrm{v})$ Human erythrocyte suspension while Indomethacin was used as standard drugs. The assay mixtures consisted of $2 \mathrm{ml}$ of hyposaline $(0.25 \% \mathrm{w} / \mathrm{v})$ sodium chloride, $1.0 \mathrm{ml}$ of $0.15 \mathrm{M}$ sodium phosphate buffer, $\mathrm{pH} 7.4,0.5 \mathrm{ml}$ of $10 \%(\mathrm{v} / \mathrm{v})$ human erythrocyte suspension,
$1.0 \mathrm{ml}$ of drugs (standard and extracts) and final reaction mixtures were made up to $4.5 \mathrm{ml}$ with isosaline. To determine the anti-inflammatory activity by HRBC membrane stabilization method, the following solutions were used.

Test solution: (4.5ml) consists of $2 \mathrm{ml}$ of hypotonic saline $(0.25 \% \mathrm{w} / \mathrm{v}), 1 \mathrm{ml}$ of phosphate buffer $(\mathrm{pH} 7.4), 1 \mathrm{ml}$ of test extract $(1 \mathrm{mg} / \mathrm{ml}-6 \mathrm{mg} / \mathrm{ml})$ in normal saline and $0.5 \mathrm{ml}$ of $10 \% \mathrm{w} / \mathrm{v}$ human red blood cells in isotonic saline.

Test control: $(4.5 \mathrm{ml})$ consists of $2 \mathrm{ml}$ of hypotonic saline $(0.25 \% \mathrm{w} / \mathrm{v}) 1 \mathrm{ml}$ of phosphate buffer $(7.4 \mathrm{pH})$ and $1 \mathrm{ml}$ of isotonic saline and $0.5 \mathrm{ml}$ of $10 \% \mathrm{w} / \mathrm{v}$ human red blood cells in isotonic saline.

Standard solution: (4.5ml) consists of $2 \mathrm{ml}$ of hypotonic saline $(0.25 \% \mathrm{w} / \mathrm{v}) 1 \mathrm{ml}$ of phosphate buffer $(7.4 \mathrm{pH})$ and $1 \mathrm{ml}$ of Indomethacin $(2.5 \mathrm{mg} / \mathrm{ml})$ and $0.5 \mathrm{ml} 10 \% \mathrm{w} / \mathrm{v}$ human red blood cells in isotonic saline. Drug was omitted in the blood control, while the drug control did not contain the erythrocyte suspension. The reaction mixtures were incubated at $37^{\circ} \mathrm{C}$ for $30 \mathrm{~min}$ and centrifuged at $3000 \mathrm{rpm}$ for $20 \mathrm{~min}$. The absorbance of the supernatant solution was measured spectrophotometrically at $560 \mathrm{~nm}$. Each experiment was carried out in triplicate and the average was taken. The percentage inhibition of haemolysis or membrane stabilization was calculated using the following equation.

\section{$\%$ Inhibition of haemolysis $=100 \times\left(A_{1}-A_{2} / A_{1}\right)$}

Where: $A_{1}=$ Absorption of hypotonic buffered saline solution alone $\mathrm{A}_{2}=$ Absorption of test sample in hypotonic solution.

\section{In-vivo anti-inflammatory activity by carrageenan induced hind paw oedema}

\section{Experimental designs}

Group -1: Control

Group -2: Indomethacin (10 mg/kg, bw, Standard)

Group -3: Aqueous extract of flower of P. Indica $(250 \mathrm{mg} / \mathrm{kg}$, p.o.)

Group -4: Aqueous extract of flower of P. Indica $500 \mathrm{mg} / \mathrm{kg}$, p.o.)

Group -5: Ethanolic extract of flower of $P$. Indica $(250 \mathrm{mg} / \mathrm{kg}$, p.o.)

Group -6: Ethanolic extract of flower of $P$. Indica $500 \mathrm{mg} / \mathrm{kg}$, p.o.)

Anti-inflammatory activity was measured using carrageenan induced rat paw oedema assay. The rats were divided into 6 groups of 6 animals each (plant extract was dissolved and administered per oral at different dose levels). Group 1 was treated as control $(0.1 \mathrm{ml}$ of $1 \%(\mathrm{w} / \mathrm{v})$ of was treated with carrageenan $(1 \% \mathrm{w} / \mathrm{v})$ in saline in the sub planter region of the right hind paw), Group 2 was administered Indomethacin $(10 \mathrm{mg} / \mathrm{kg}$, bw) and considered as standard and others group were treated with different doses of $P$. indica aqueous and ethanolic extracts. The paw volume was measured plesthysmometrically (model 7140, Ugo Basil, Italy). Prior to injection of carrageenan, the average volume of the right hind paw of each rat was calculated. At 1, 2, 3, 4 and $5 \mathrm{hr}$ after injection paw volume was measured. Reduction in the paw volume compared tothe vehicle-treated control animals was considered as anti-inflammatory response 17 .

\section{Statistical analysis}

All analysis was performed using graph pad prism for Windows. All statistical analysis is expressed as mean \pm 
standard error of the mean (SEM). Data were analyzed by one way ANOVA, where applicable $\mathrm{p}<0.05$ was considered statistically significant, compared with vehicle followed by Dunnett's test.

\section{RESULTS AND DISCUSSIONS}

The crude extracts so obtained after each of the successive soxhlet extraction process were concentrated on water bath by evaporation the solvents completely to obtain the actual yield of extraction. The percentage yield of extraction is very important in phytochemical extraction in order to evaluate the standard extraction efficiency for a particular plant, different parts of same plant or different solvents used. The yield of extracts obtained from the flower of $P$. Indica plants using petroleum ether, chloroform, ethanol and aqueous as solvents is depicted in the Table 1.

Table 1: Results of percentage yield of various extracts of $P$. indica flowers

\begin{tabular}{|c|c|c|c|c|}
\hline \multirow{2}{*}{ Plant Name } & \multicolumn{4}{|c|}{ Percentage yield (\%) } \\
\cline { 2 - 5 } & Pet. Ether & Chloroform & Ethanol & Aqueous \\
\hline P. indica & 1.10 & 5.84 & 9.25 & 10.98 \\
\hline
\end{tabular}

The physical constituent's estimation of the drugs is an essential parameter to determine adulteration or inappropriate handling of drugs. The physicochemical characters of powder drug of flower of $P$. indica such as total alcohol soluble extractive, water soluble extractive, ash value, acid insoluble ash, and water soluble ash, loss after drying and foreign substances are given in Table 2 . The $P$. indica flower showed less moisture content; it was $2.0832 \%$. Moisture content of drugs could be at minimal level to discourage the growth of bacteria, yeast or fungi during storage. These can serve as a valuable basis of information and provide suitable standards to establish the quality of this plant material as future prospects. An ash values are used to decide quality and purity of crude drug, it indicates presence of various impurities like, silicate, oxalate and carbonate. The water soluble ash is used to determine the quantity of inorganic compounds present in drugs. The acid insoluble ash helps to estimate the amount of silica present in the material. The total water soluble portion of the ash is considered as water soluble ash. Less amount of these three parameters indicate that the inorganic matter and silica were less in flower of $P$. indica.

Table 2: Physico-chemical parameters of flower of $P$. indica

\begin{tabular}{|c|c|c|}
\hline S/No. & Parameters & $\begin{array}{c}\text { Values Obtained } \\
(\% w / w)\end{array}$ \\
\hline 1. & Total Ash (TA) & 5.6183 \\
\hline 2. & Water Soluble Ash (WSA) & 3.8027 \\
\hline 3. & Acid Insoluble Ash (AIA) & 1.9505 \\
\hline 4. & Moisture Content (MC) & 2.0832 \\
\hline 5. & Swelling Index (SI) & 1.1039 \\
\hline 6. & Foreign Organic Matters (FOM) & 0.0801 \\
\hline 7. & Water Soluble Extractive value & 18.5719 \\
\hline 8. & Alcohol Soluble Extractive value & 11.7325 \\
\hline 9. & Pet. Ether Soluble Extractive value & 4.0985 \\
\hline
\end{tabular}

The result of qualitative phytochemical analysis of the crude powder flower of $P$. indica was shown in Table 3. Aqueous and ethanolic extract of flower of $P$. indica sample showed the presence of carbohydrates, glycosides, protein \& amino acid, steroids, triterpenoids.

Table 3: Phytochemical evaluations of different extracts of $P$. indica

\begin{tabular}{|c|c|c|c|c|c|}
\hline \multirow{2}{*}{ S/No. } & Constituents & \multicolumn{4}{|c|}{ Extract } \\
\cline { 3 - 6 } & & Pet. Ether & Chloroform & Ethanol & Aqueous \\
\hline 1 & Carbohydrates & - & - & + & + \\
\hline 2 & Glycosides & - & - & + & + \\
\hline 3 & Alkaloids & - & - & - & - \\
\hline 4 & Protein \& Amino acid & + & + & + & + \\
\hline 5 & Tannins \& Phenolic & - & - & - & - \\
\hline 6 & Flavonoids & + & + & + & + \\
\hline 7 & Fixed oil and Fats & - & - & - & - \\
\hline 8 & Steroids \&Triterpenoids & + & + & + & + \\
\hline 9 & Waxes & - & - & - & - \\
\hline 10 & Mucilage \& Gums & - & - & + & + \\
\hline
\end{tabular}


The acute oral toxicity study was done according to the OECD 425 guidelines. No adverse changes and mortality were observed in animals, which orally received hydroalcoholic extract $(2000 \mathrm{mg} / \mathrm{kg})$ of $P$. indica flowers. This indicates that $2000 \mathrm{mg} / \mathrm{kg}$ is maximum safe dose. So $1 / 8^{\text {th }}$ and $1 / 4^{\text {h }}$ i.e. 250 and $500 \mathrm{mg} / \mathrm{kg}$ of body weight, of the maximum safe dose were selected for studying in vivo antiinflammatory activity. During inflammation, lysosomal hydrolytic enzymes are released into the sites which cause damages of the surrounding organelles and tissues with attendance variety of disorders. Various methods were employed to screen and study drugs, chemicals, herbal preparations that exhibit antiinflammatory properties or potentials. These techniques include uncoupling of oxidative phosphorylation (ATP biogenesis linked to respiration), inhibition of denaturation of protein, erythrocyte membrane stabilization, lysosomal membrane stabilization, fibrinolytic assays and platelet aggregation. In the present study, stabilization of erythrocyte membranes exposed to both heat and hypotonic induced lyses was employed due to its simplicity and reproducibility. The aqueous and ethanolic extract of the flowers of $P$. indica was studied for in vitro anti-inflammatory activity by HRBC membrane stabilization method. Five different concentration of aqueous and ethanolic extract were used among which concentration at 5 $\mathrm{mg} / \mathrm{ml}$ showed $56.38 \%$ \& protection of HRBC in hypotonic solution. All the results were compared with standard indomethacin, which showed $89.50 \%$ protection. The activity may be due to the presence of one or more phytochemical constituents present in the extract. The result obtained has been supported by Photomicrographical pictures of the HRBC (Figure 1-3). The extracts exhibited membrane stabilization effect by inhibiting hypotonicity induced lyses of erythrocyte membrane. The erythrocyte membraneis analogous to the lysosomal membrane and its stabilization implies that the extract may as well stabilize lysosomal membranes. Stabilization of lysosomal membrane is importantin limiting the inflammatory response by preventing the release of lysosomal constituents of activated neutrophil such as bactericidal enzymes and proteases, which cause further tissue inflammation and damage upon extra cellular release 15,18 .

Table 4: In-vitro anti-inflammatory activity of $P$. indica flowers by red blood cell membrane stabilization method

\begin{tabular}{|c|c|c|c|}
\hline Treatment & Conc. $\mathbf{m g} / \mathbf{m l}$ & Absorbance & \%Inhibition \\
\hline \multirow{3}{*}{ Control } & - & $0.6670 \pm 2.99$ & 49.47 \\
\cline { 2 - 4 } & 1 & $0.3370 \pm 2.44^{\mathrm{a}}$ & 51.87 \\
\cline { 2 - 4 } & 2 & $0.3210 \pm 2.44^{\mathrm{c}}$ & 54.88 \\
\cline { 2 - 4 } & 3 & $0.3009 \pm 2.44^{\mathrm{b}}$ & 55.12 \\
\cline { 2 - 4 } & 4 & $0.2993 \pm 2.44^{\mathrm{a}}$ & 56.38 \\
\hline \multirow{4}{*}{ Aqueous extract } & 5 & $0.2909 \pm 0.03^{\mathrm{c}}$ & 9.5 \\
\cline { 2 - 4 } & 2 & $0.7308 \pm 2.00^{\mathrm{c}}$ & 15.14 \\
\cline { 2 - 4 } & 3 & $0.7680 \pm 3.16^{\mathrm{b}}$ & 16.68 \\
\cline { 2 - 4 } & 4 & $0.7827 \pm 2.44^{\mathrm{a}}$ & 21.63 \\
\cline { 2 - 4 } & 5 & $0.8113 \pm 2.44^{\mathrm{c}}$ & 33.28 \\
\hline Standard drug & 2.5 & $0.8890 \pm 2.00^{\mathrm{b}}$ & 89.50 \\
\hline \multirow{2}{*}{ Indomethacin } & & 0.0700 & \\
\hline
\end{tabular}

Values are expressed as X (Mean) +SEM, $n=3$. (One way ANOVA followed by Student t-test). Statistically significance of aP $<0.05$, $\mathrm{bP}<0.01, \mathrm{cP}<0.001$ and dNS in comparison to respective control.

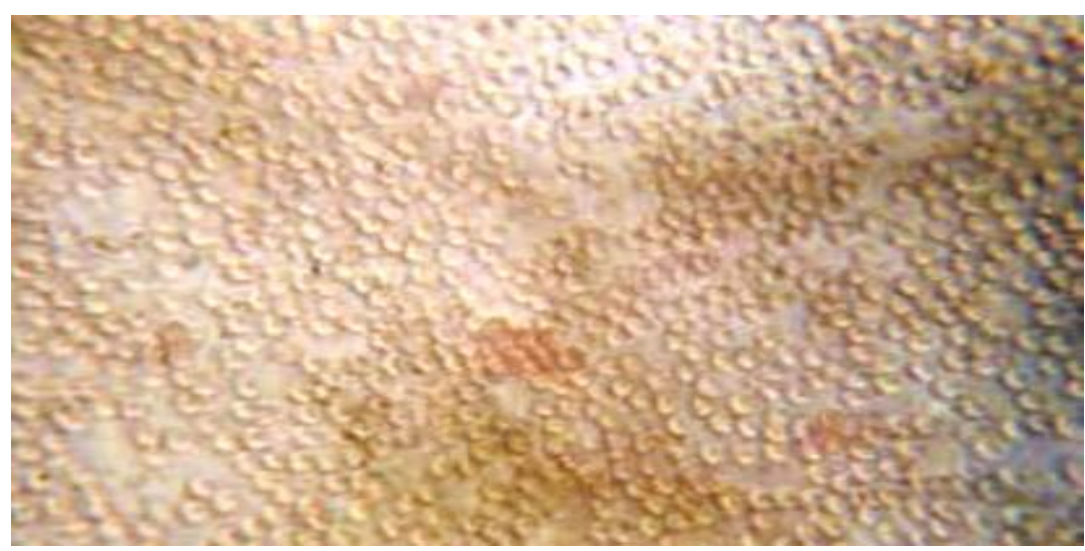

Figure 1: HRBC in Isotonic Solution 


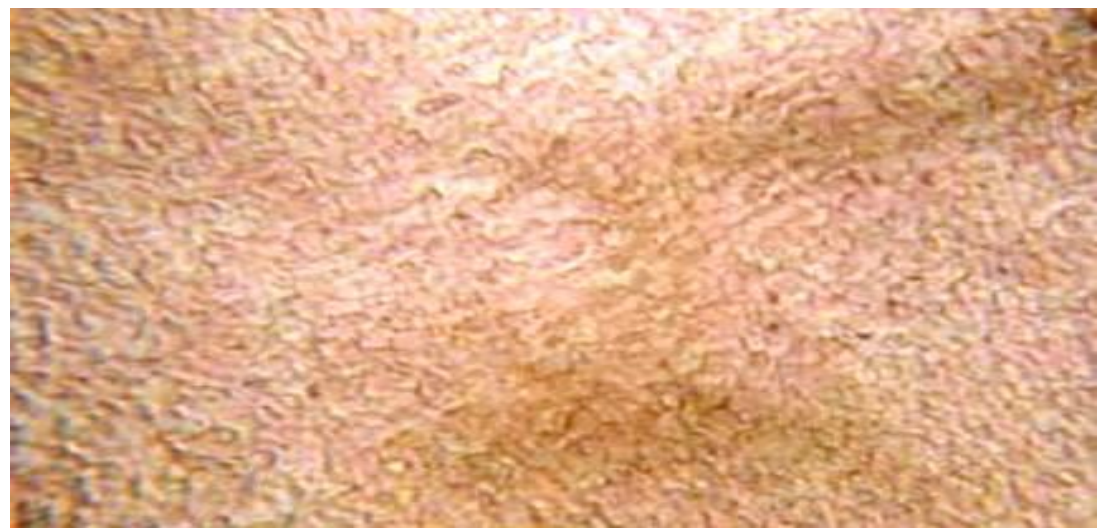

Figure 2: HRBC in hypertonic solution -control (lysis of hypertonic induced HRBC membrane)

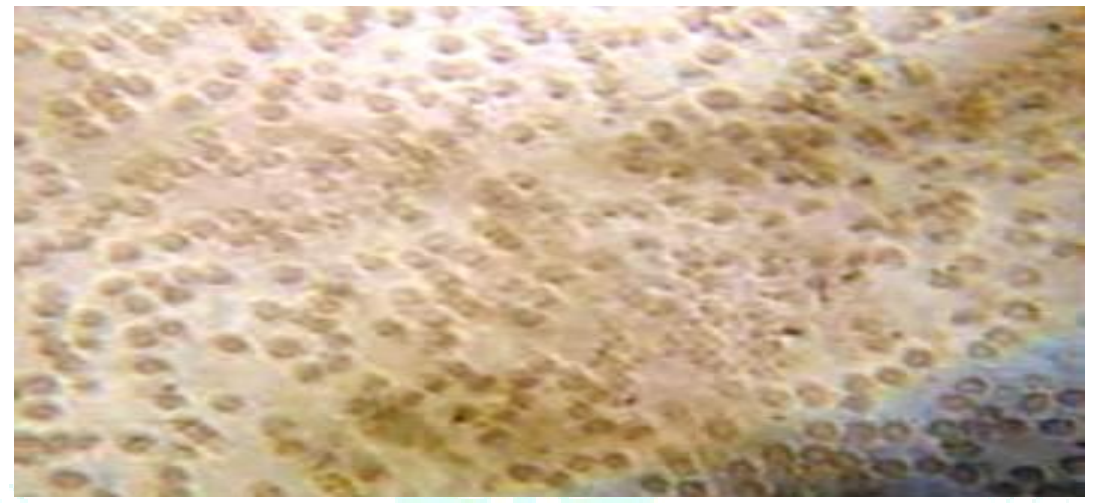

Figure 3: RBC in Hypertonic solution with plant extract (AE) $(5 \mathrm{mg} / \mathrm{ml}$ ) (protection of hypertonic induced HRBC membrane lysis)

The aqueous and ethanolic extract of $P$. indica flowers evaluated for in vivo-anti-inflammatory activity in animal models and results are summarized in table 5 . The results obtained indicates that the extract found to have significant $(\mathrm{P}<0.01)$ anti inflammatory activity in rats. The aqueous extract at the test doses 250 and $500 \mathrm{mg} / \mathrm{kg}$ b.w. reduced the edema induced by carrageenan by $38.78 \%$ \& $32.72 \%$ respectively at $5 \mathrm{hr}$, whereas the ethanolic extract at the test doses 250 and $500 \mathrm{mg} / \mathrm{kg}$ b.w. reduced the edema induced by carrageenan by $33.93 \% \& 33.33 \%$ as compared to standard drug which showed $55.75 \%$ of inhibition as compared to the control group (graph 43).

Table 5: \% Inhibition of $P$. indica extracts on carrageenan induced edema

\begin{tabular}{|c|c|c|c|c|c|c|}
\hline Treatment & Dose & \multicolumn{6}{|c|}{ \% Inhibition } \\
\cline { 5 - 7 } & $\mathbf{n g} / \mathbf{k g})$ & $\mathbf{1 h}$ & $\mathbf{2 h}$ & $\mathbf{3 h}$ & $\mathbf{4 h}$ & $\mathbf{5 h}$ \\
\hline Control & - & - & - & - & - & - \\
\hline Standard Drug & 10 & 27.90 & 55.24 & 55.17 & 54.32 & 55.75 \\
\hline Aqueous Extract & 250 & 23.62 & 23.75 & 30.45 & 29.62 & 38.78 \\
\hline Aqueous Extract & 500 & 15.11 & 21.54 & 22.98 & 25.30 & 32.72 \\
\hline Ethanolic Extract & 250 & 16.27 & 22.65 & 27.90 & 28.39 & 33.93 \\
\hline Ethanolic Extract & 500 & 13.95 & 19.33 & 23.56 & 25.92 & 33.33 \\
\hline
\end{tabular}

\section{CONCLUSION}

It can be concluded that from present investigation the physicochemical and preliminary phytochemical investigation study of $P$. indica flowers yielded a set of standards that can serve as an essential basis of evidence to determine the identity and to determine the quality and purity of the plant material as per its future perspectives. The phytochemical investigation gave valuable information about the different phytoconstituents present in the plant, which helps the future investigators concerning the selection of the particular extract for further investigation of isolating the active principle and also gave idea about different phytochemical have been found to possess a wide range of activities. The results of the present study have provided scientific basis for the traditional uses of flowers of $P$. indica in inflammation, possessing significant antiinflammatory activity. This may be due to the presence of many phytoconstituents which deserve further studies to isolate the active constituent responsible for the activity and to find out its mechanism of action. 


\section{REFERENCES}

1. Kumar V, Abbas AK, Fausto N. In: Robbins and Cotran Pathological basis of disease. 7th Ed, Philadelphia, Elsevier Saunders. 2004:47-86.

2. Rang HP, Dale MM, Ritter JM. Anti-inflammatory and immunosuppressant drugs, chapter 14. Flower RJ; Rang and Dale's Pharmacology, 6th Ed. Elsevier Publication. 2008; 22645.

3. Sangita K, Shukla G, Sambasiva Rao A. The present status of medicinal plants-Aspects and prospects. Int J Res Pharm Biomed Sci 2011; 2:19-22.

4. Karim A, Sohail MN, Munir S, Sattar S. pharmacology and phytochemistry of Pakistani herbs and herbal drugs used for treatment of diabetes. Int J Pharmacol 2011; 7:419-39.

5. Pattari LS, Muchandi VN, Haricharan KN, Himabindu GM, Tejaswi CH, Ramanjaneyulu K, et al. Study of analgesic acxtivity of Litsea glutinosa (L.) ethanolic extract on swiss albino mice. Int J Pharm Sci Res 2010; 1:93-7.

6. WHO. General Guidelines for Methodologies on Research and Evaluation of Traditional Medicine WHO/EDM/TRM/2000. 1, Geneva, Switzerland, 2000.

7. Mulla WA, More SD, Jamge SB, Pawar AM, Kazi MS, Varde MR Evaluation of antiinflammatory and analgesic activities of ethanolic extract of roots Adhatoda vasica Linn. Int J Pharm Tech Res 2010; 2:1364-8.

8. Shinde P. R., Patil P. S., Bairagi V. A. Phytopharmacological Review of Plumeria species. Sch Acad J Pharm 2014; 3(2):217227.

9. The Unani pharmacopeia of India. 2007-2010. Department of AYUSH, Ministry of health and family welfare, Government of India.

10. Nayak A, Garg M, Jain S, Khan MA, Jain DK, Khan N. AntiUrolithiatic and invitro-invivo anti-oxidant effects of methanolic extract of thunbergia laurifolia on ethylene glycol-induced kidney calculi in rats. Sch Acad J Pharm 2019; 8 (3):94-104

11. Jain DK, Nayak A, Patel P, Jain A, Khan MA. Appraisal of in vitro antioxidant and in vivo anti-inflammatory activities of various extracts from the fruits of vitis vinifera L. Sch Acad J Pharm 2019; 8 (3):86-93.

12. Jain DK, Patel NS, Nagar H, Patel A, Chandel HS. Anti-arthritic activity of tridax procumbens ethanolic extract of leaves. RGUHS J Pharm Sci 2012; 2(4):80-86.

13. Guideline Document on Acute oral Toxicity Testing, Series on Testing and Assessment No. 423. Paris: Organization for Economic Co-Operation and Development, OECD Environment, Health and Safety Publications; 1996. Available from: http//www.oecd.org/ehs.

14. Jonsson $M$, Jestoi $M$, Nathanail AV, Kokkonen $U M$, et al. Application of OECD Guideline 423 in assessing the acute oral toxicity of moniliformin. Food Chem Toxicol, 2013; 53:27-32.

15. Sadique J, Al-Rqobah NA, Bughaith MF, El-Gindy AR. The bioactivity of certain medicinal plants on the stabilization of RBC membrane system. Fitoterapia, 1989; LX: 525-532.

16. Oyedapo 00, Akinpelu BA, Orefuwa SO. Anti-inflammatory effect of Theobroma cacao, root extract. J Trop Med Plants, 2004; 5:161-166.

17. Ahmed F, Selim MST, Das AK, Choudhuri MSK. Antiinflammatory and antinociceptive activities of Lippia nodiflora Linn. Pharmazie, 2004; 59(4):329-30.

18. Gupta S, Kohli S, Dwivedi S. In-Vitro anti-inflammatory activity of Sarcostemma acidum Wight. \& Arn. Indian herb by Human red blood cell membrane stabilization method. Int J Pharm Teach Prac 2011; 2(4):184-188. 